症例報告

順天堂医学. 2012,58

P. $441 \sim 444$

誤飲された魚骨による虫垂穿孔の 1 例

吉 田 範 敏*11

渡野辺郁 雄 $* 11$

丸山俊 朗*1)

井 原

厚*1)

\begin{tabular}{|c|}
\hline 息 \\
\hline
\end{tabular}

症例は 63 歳, 男性. 右鼠径部の疼痛を主訴に来院. 腹部 CT 検査で骨盤腟内の低吸収域と盲腸下端に線状の高吸収域を認めた. 魚骨等の異物を疑い，手術施行．虫垂より魚骨が穿孔し後腹膜に膿瘍を形成していた．本邦の虫垂異物は，魚骨が原因となるこ とが多い。今回 CTで魚骨は疑われたが，術前診断とまでは至らなかった，術前に診断することは非常に困難であるが，魚骨に よる虫垂穿孔も考え, 注意深い術前評価が必要であると思われた.

キーワード：魚骨, 虫垂穿孔, 虫垂異物

\section{はじめに}

誤って飲み込まれた魚骨は，自然排泄されることが ほとんどであるが，まれに消化管穿孔や穿通を起こし て腹膜炎や膿瘍形成をすることがある，本邦における 誤飲異物による穿孔, 穿通の多くは魚骨が原因である とされている ${ }^{12)}$. 今回われわれは誤飲された魚骨に よる虫垂穿孔の 1 例を経験したので文献的考察を加え 報告する．

\section{症例}

症例：63歳, 男性.

主訴：右鼠径部から大腿部にかけての疼痛

既往歴：特記すべきことなし.

現病歴：5日前から続く右鼠径部から大腿部にかけ ての疼痛を主訴に来院した，疼痛強く $39^{\circ} \mathrm{C}$ の発熱も 認めたため入院となった.

入院時現症: 意識清明. 血圧 $140 / 78 \mathrm{mmHg}$, 脈拍 70 回/分, 体温 $39.0^{\circ} \mathrm{C}$. 腹部の反跳痛, 筋性防禦は認 めなかったが, 右鼠径部から大腿部にかけての圧痛を 認めた.

血液検查所見：白血球数 $15,800 / \mathrm{mm}^{3}$, CRP 7.8 $\mathrm{mg} / \mathrm{d} l$ と炎症所見がみられた。 その他の異常所見は認 めなかった.

腹部単純レントゲン検查所見：バリウムを上行結 腸喤室内に認めたが, 石灰化像や腹腔内遊離ガス像は 認めなかった (図-1).

腹部超音波検查所見：鼠径部から腹腔内にかけて

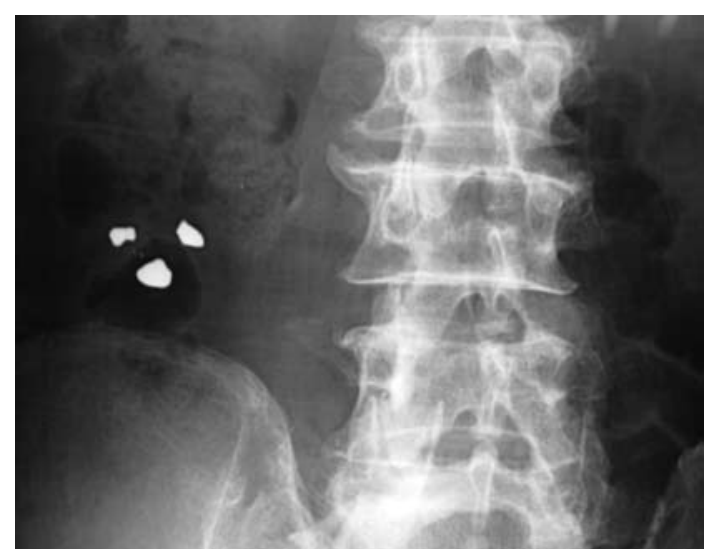

図-1＼cjkstart腹部単純レントゲン検査 腹部単純レントゲン検査 : 大腸悡室内の残存バリ ウムを認めた。

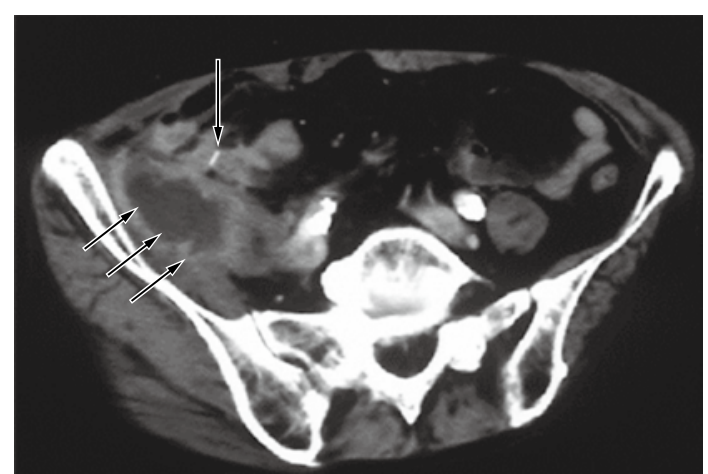

図-2 腹部 $\mathrm{CT}$ 検査

腹部CT検查：盲腸下端に線状の高吸収域像を認 め(矢印) 異物が疑われた。低吸収域像の周囲は 造影増強効果がみられた。

*1) 浅草病院外科

* 2) 順天堂大学医学部附属順天堂医院救急科

〔May 24, 2012 原稿受領〕〔July 6, 2012 揭載決定〕 

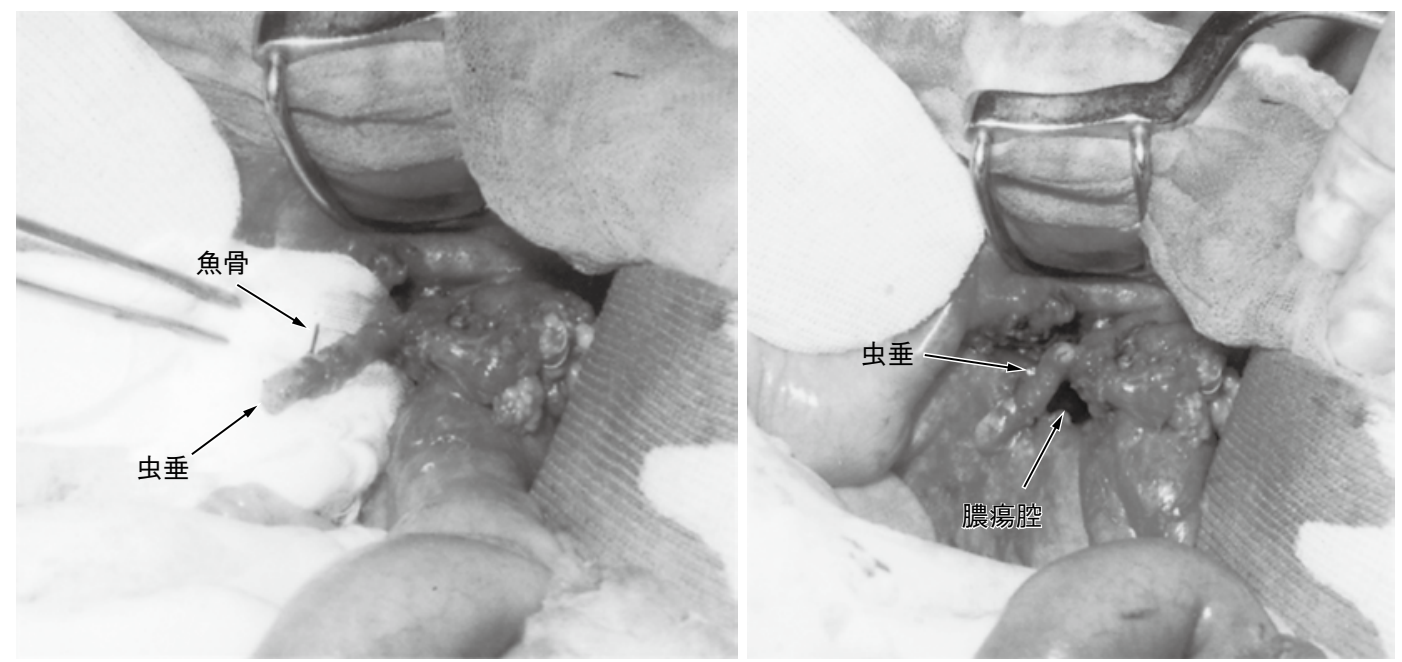

図-3 手術所見

手術所見：大網と回腸の癒着を剥離したところ虫垂より魚骨が穿孔していた．そこから後腹膜膿瘍を形成 していた.

液体貯留を認めたが，虫垂の同定はできなかった．

腹部 CT 検查所見：右腸腰筋に沿って骨盤腔内から 大腿前面にかけての低吸収域像を認めた。さらに盲腸 下端に線状の高吸収域像を認め異物が疑われた。低吸 収域像の周囲は造影増強効果がみられ肉芽の形成が考 えられた．腹腔内遊離ガス像は認めなかった(図-2).

以上の所見から，盲腸内異物による消化管穿通また は上行結腸憩室炎の診断で同日緊急手術を施行した。

手術所見：開腹時, 回盲部付近は大網と回腸が癒着 し，一塊となっていた．大網と回腸の癒着を剝離した ところ虫垂が確認され，魚骨により虫垂が穿孔し，周 囲に膿瘍を形成していた（図-3)。虫垂根部は処理可 能であり, 回盲部切除は行わず虫垂切除のみを行っ た．膿瘍腔を十分洗浄，ドレーンを留置し，手術を終 了した。

切除標本所見：虫垂の中央付近に魚骨があり魚骨 は虫垂から穿通していた，魚骨の長さは約 $2 \mathrm{~cm}$ ，虫 垂壁は肥厚していた (図-4).

病理組織学的所見 : 全層に炎症細胞浸潤が広がり, Phlegmonous appendicitisの診断であり，悪性所見 はなかった.

術後の問診においても誤飲した経緯，日時は不明で あった。そのため魚の種類は同定できず，形状からの 魚の同定もできなかった. 術後経過は順調で術後第 21 病日に退院となった。

\section{考察}

誤飲された異物は，通常消化管に留まることなく短 期間で便とともに自然排泄されるか，留まったとして も上部消化管内で内視鏡的に摘出されることも多く, 穿孔，穿通などの頻度は $1 \%$ 前後とされている ${ }^{3)}$. 消

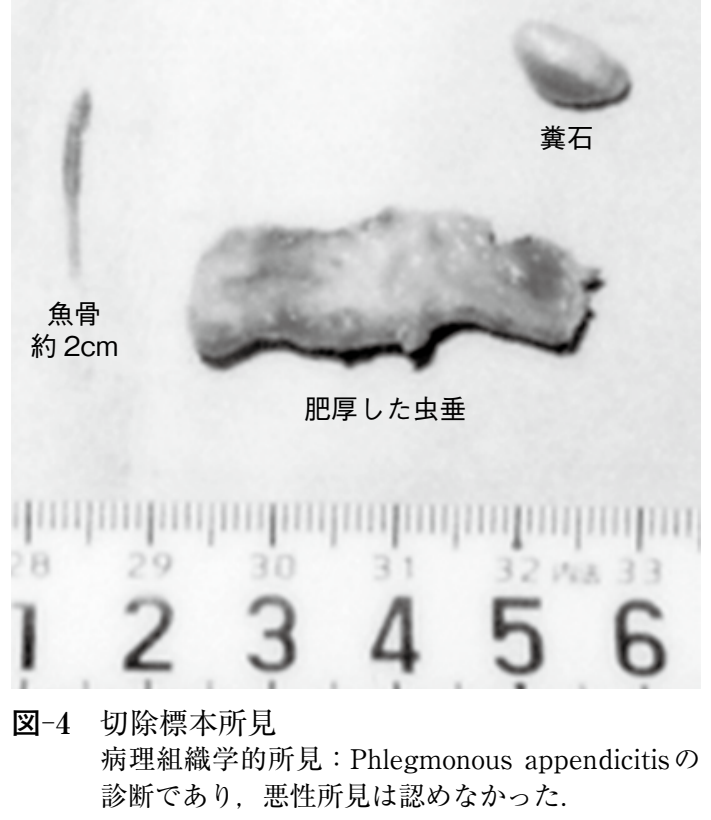

化管異物としては小児が多い（電池，おもちゃなど） が，成人では義歯，PTP (Press through package), 安全ピン，魚骨などが多くみられる，そのなかで，消 化管穿孔の原因となる異物は本邦では魚骨が圧倒的に 多く $(90 \%$ 近く $)$ その他爪楊枝, 鳥の骨, PTPなどが 報告されている ${ }^{1)}$. 医学中央雑誌から 1997 年 2011 年の最近 15 年間の異物による穿通，穿孔症例をみて みると，爪楊枝による消化管穿孔報告例は 11 例であっ たのに対し，魚骨は251例であった（会議録は除く）。 そこで，本邦における最近 15 年間の魚骨による消化 管穿孔，穿通251例を検討した。

年齢は 50 歳以上が $85.0 \%$ 以上を占めていた，異物 
の誤飲を起こしやすい要因として, 高齢, アルコール 多飲, 視覚障害, 早食いなどがあげられているが4), 今回の検討でも 50 歳以上が $85.0 \%$ 以上とその傾向が みられている。性別は男性 $66.1 \%$, 女性 $33.9 \%$ と男 性に多く，主訴は $43 \%$ が腹痛を訴えており，33\%の 症例に膿瘍形成による腹部腫瘤を認めている。実際， 腹腔内膿瘍や肉芽形成は $59.1 \%$ にみられていた。自 験例でも膿瘍周囲に肉芽を形成しCT検查において造 影増強効果がみられた。

魚骨による穿孔，穿通の好発部位は，大腸が $37.5 \%$ と最も多く，そのなかでは横行結腸に多くみられた. しかし食道，胃や小腸にも $30 \%$ 前後みられ，どの部 位にもまんべんなく起こりうると考えられる，そのな かで虫垂は $4.4 \%$ であり比較的まれであった，虫垂は 入口部が狭小であり異物は迷入しにくいが, 脱出も困 難でありいったん迷入すると特に魚骨は内部で固定さ れてしまい, 先端が鋭利であるため穿孔しやすいと考 えられる. その pin hole状の限局性炎症から次第に周 囲に炎症が及んでいくと考えられた ${ }^{5)}$. 一般的に腸管 穿孔を起こす条件として腸管に癒着, 狭窄などの器質 的変化があること，もしくは異物が腸管直径より大き いことが重要な因子となるが ${ }^{1)}$, 魚骨は先端が鋭利 であり, 何らかの原因で先端がひっかかった場合, 穿 通，穿孔にいたると考えられる．虫垂の動きははっき りわかっていないが, 弱いながらも末梢に向かう蠕動 があると考えられている．そのため先端が鋭利な魚骨 が迷入した場合, そこから排出されるのは困難であ る. 自験例は虫垂の先端に賴石も合併しており, 虫垂 の慢性炎症が起こっているところに魚骨が迷入し, 強 い炎症が起きたと考えられた。

画像所見であるが, RetrospectiveにみたCTの診 断率は高いが, 術前に魚骨による消化管穿孔とはっき りしていた正診率は $22.3 \%$ であったと報告されてい $る^{7)}$. 自験例も含め, 魚骨の場合本人が誤飲したとい う自覚に乏しいのと腹腔内遊離ガス像を認めることが まれであることが起因していると考えられる，自験例 でも Retrospectiveにみてみると術前に考えていた盲 腸下端ではなく, 虫垂の中にHigh densityの線状石 灰化像が確認される。この画像を念頭に置いていれ ば，術前確定診断をすることも可能であり，それには CT検査が有用であると考えられた。しかし実際には 術前に魚骨による虫垂炎, 虫垂穿孔と診断された症例 は本邦報告で, わずか 2 例であり, その診断はきわめ て困難であると考えられた ${ }^{8)}$.

虫垂症例の手術術式は, 自験例を含め虫垂切除術が $58.4 \%$ と最も多く, 回盲部切除を行った症例は $33.3 \%$
にみられた，症状出現より10日以内に手術が行われ た急性型とそれ以降に行われた慢性型に分類してみる と, 急性型が 4 割で慢性型が 6 割と慢性型が多くみら れた. 慢性型では何か別のものによる腹腔内膿瘍や悪 性疾患が否定できず，診断に時間がかかっている症例 がみられている。

自験例は膿瘍腔が大きくはじめから開腹で手術を 行っているが, 近年腹腔鏡下手術の普及に伴い, 異物 による穿孔に対して腹腔鏡下手術を選択する報告が増 加している ${ }^{9010)}$. 腹腔鏡下手術は腹腔内全体を観察す ることが可能で, 近接での観察も可能であるため魚骨 のような小さい異物の検索には有用である.ささらに切 開創が小さく, 整容性も優れている点で単孔式腹腔鏡 下手術も導入され始めている ${ }^{11)}$.

\section{結語}

誤飲された魚骨による虫垂穿孔の1例を経験したの で, 最近 15年間に本邦で報告された症例の検討を加 え報告した．本疾患は術前に診断するのはきわめて困 難であるが，CT検査を中心とした注意深い術前評価 により診断に近づけると考えられた。

\section{文献}

1) 石橋新太郎：腹腔内異物に関する臨床的ならびに実験的研 究. 日外会誌, $1961 ; 62 ： 489 \sim 509$.

2) Perelman $H:$ Toothpick perforation of the gastrointestinal tract. J Abdom Surg, $1962 ; 4: 51 \sim 53$.

3) Gracia C, Frey C, Bodai B : Diagnosis and management of ingested foreign bodies. Ann Emerg Med, $1984 ; 13$ : $30 \sim 34$.

4) 和久利彦 : 異物による小腸穿孔の 2 例. 日腹部救急医会誌, $2006 ; 26: 433 \sim 436$.

5）犬飼道雄, 岡野圭一, 唐澤幸彦, 他：魚骨による虫垂穿通 の1例. 日消外会誌, $2002 ; 35: 1418 \sim 1422$.

6) 二村直樹, 松友将純, 市橋正嘉, 他 : 魚骨による消化管穿 孔の 2 例. 手術, $2003 ; \mathbf{5 7}: 367 \sim 369$.

7) 葉季久雄, 井上 聡, 渡辺靖夫, 他 : 術前に診断しえた魚 骨による回腸穿孔の 1 治験例一過去 10 年間の魚骨による消 化管穿孔の 271 例の分析一. 日消外会誌, $2001 ; 34$ : 1640 1644.

8) 花本尊之, 井上行信, 砂原正男, 他 : 魚骨による虫垂穿孔 の1例. 日臨外会誌, $2008 ; 69: 576 \sim 580$.

9) 窪田寿子, 松本英男, 浦上 淳, 他：超音波検査で診断し, 腹腔鏡補助下手術を行った空腸魚骨穿孔の1例. 日腹部救 急医会誌, $2007 ; 27: 529 \sim 532$.

10) 伴登宏行 : 腹腔鏡下手術が有用であった嚥下魚骨による小 腸穿孔の1例. 日腹部救急医会誌, $2005 ; 66: 1918$ 1921.

11）柳本喜智，上島成幸，赤松大樹，他 : 単孔式腹腔鏡下にて 治療しえた魚骨による小腸穿孔性腹膜炎の 1 例. 日鏡外会 誌, $2012 ; 17:$ 193 196. 


\title{
A GASE OF PERFORATION OF THE APPENDIX BY A FISH BONE
}

\author{
NORITOSHI YOSHIDA*1), IKUO WATANOBE*1), TOSHIROU MARUYAMA*1),

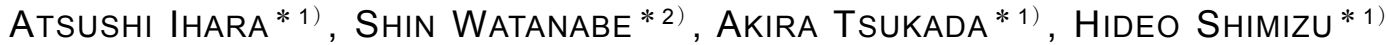 \\ *1) Department of Surgery, Asakusa hospital, Tokyo, Japan, *2) Department of EMERgency Medicine, \\ JUNTENDO UNIVERSITY HOSPITAL, TOKYO, JAPAN
}

\begin{abstract}
A 63-year-old man was admitted to our hospital with right inguinal pain, and abdominal CT scan showed an abscess of the ileocecal area and linear high density in the lower part of the cecum. We suspected the presence of a foreign body such as a fish bone, and an emergency operation was carried out. A fish bone was found in the abscess adjacent to the perforated appendix. In Japan, many cases of perforation of the appendix by fish bone have been reported, but preoperative diagnosis is very difficult. We must assume the presence of a fish bone if a linear high density is detected on CT scan, and careful clinical assessment is required.
\end{abstract}

Key words : fish bone, perforated appendicitis, foreign body in the appendix 